\title{
GROWTH AND LEAF PROTEINS OF FENUGREEK PLANTS (TRIGONELLA FOENUM GRAECUM) GROWN UNDER THE EFFECT OF WATER STRESS AND TREATMENT WITH SOME GROWTH REGULATORS
}

\author{
HUSSEIN, E. A.* and AL-SHEMAIRY, M. A. ** \\ * Botany and Microbiology Department, Faculty of Science, Al-Azhar University, \\ Cairo, Egypt. \\ ** Biology Department, Sana'a University, Sana'a, Yemen Republic.
}

\begin{abstract}
In the present study, Fenugreek (Trigonella foenum graecum) seedlings were divided into three groups, the first of which was allowed to grow under normal irrigation conditions (full field capacity), the second under moderate water stress (50\% of the field capacity) and the third under severe water stress ( $25 \%$ of the field capacity). With the beginning of stress treatment, the seedlings of each group were subdivided into four subgroups. The first represented control, the second sprayed with $\mathrm{GA}_{3}$ (1000 p.p.m), the third with IBA (100 p.p.m) and the fourth with kinetin (100 p.p.m). After two weeks of treatment plants were collected for measurement of plant growth and analysis of leaf proteins to study the effect of water stress and some of the plant growth regulators on growth and gene expression. Some of the growth characters were retarded by water stress. Growth regulators improved the growth of plants under normal irrigation conditions and could overcome some of the adverse effects of stress on water stressed plants. Some alterations on the leaf-protein SDS-PAGE patterns were observed in plants in response to the effect of water stress and the application of growth regulators. $\mathrm{GA}_{3}$ treatment resulted in the appearance of two novel bands under normal irrigation and disappearance of the stress induced band. IBA resulted in the disappearance of a band that presents in the corresponding control while kinetin resulted in the over-expression of another band.
\end{abstract}

Key words: water stress, Fenugreek, SDS-PAGE, gene expression, growth hormones

\section{Introduction}

Fenugreek plant is a flowering annual indigenous to countries on the eastern shores of Mediterranean. It is widely cultivated in India, Egypt, Ethiopia, and Morocco and occasionally in England (Polhil and Raven 1981). Fenugreek is becoming popular around the world with its extract used to flavor cheese in Switzerland, artificial maple syrup and bitter-run in Germany, roasted seeds as coffee-substitute. In Africa, seed powder is mixed with flour to make flat-bread in Egypt; the seeds are also used as an anti-diabetic. Whole seed and dried plant are used as insect and pest repellent in grain storage. Oil is used in perfumery in France (Rajagopalan, 1998). Research reports in the recent years have indicated that fenugreek can be a remedy to diabetes by lowering blood sugar and cholesterol levels (Sharma, 1990). 
Celina et al. (2005) defined drought stress as a complex syndrome involving not only water deprivation but also nutrient limitation, salinity, and oxidative stresses and that most environmental stress forms as drought, salt, low and high temperature; have a common denominator. In many countries of the Middle East where fenugreek plant is being cultivated, water stress exists. Wangaxia et al. (2003) illustrated that abiotic stresses such as drought stress will lead to a loss of about $30 \%$ of the cultivated lands by the year 2025 and about $50 \%$ by the year 2050 in some parts of the world, and suggested that abiotic stresses such as drought should be given high research priority. Since many plants can not escape drought stress, they adapt themselves on morphological as well as biochemical and molecular levels. With respect to the morphological level, it has been frequently reported that water stress reduce the general features of plant growth (Singh-Sangwan et.al., 1994; Banuls et al., 1997; Al-Hakimi et al., 2001; Al-Hakimi, 2003; Abdul Baset, 2005).

There are strong evidences that abiotic stresses, like water stress affect gene expression and gene products e.g. (osmoprotective compounds). Exposure of plants to water-limiting environments during the plant's vegetative, reproductive, or early embryo development phases appears to trigger a set of physiological and developmental changes and accordingly a number of biochemical changes that ultimately result in an increase or a decrease in the biosynthesis of a large number of distinct proteins that alter enzyme activity.

Changes in the protein profile may take place in response to many reasons like (transcription rate, RNA stability, post-transcriptional control, and protein turnover, etc.). Several genes have been described to respond to dehydration at the transcriptional level in a variety of plant species (Smirhoff and Colombe, 1989; Skriver and Mundy, 1990; Luchi et al., 1996; shinozaki and Yamaguchi-Shinozaki, 1996; Bray, 1997; Oliver et al., 1998; Tabaeizadeh, 1998). Metabolic changes in response to the effect of water stress include reduction in photosynthetic capacity (Ritchie et al. 1990), significant increases in the proteolytic and amylolytic activities (Hussein 1993), accumulation of organic acids such as malate, citrate and lactate and osmoprotective substances like proline, sugars and betaine (Bohnert et al., 1995; shinozaki and Yamaguchi-Shinozaki, 1996; Bray, 1997; Tabaeizadeh, 1998).), and an overall reduction in protein synthesis (Mason et al., 1988). Lilach et al. (2002), illustrated that the extreme drought tolerance of the desert legume Retama. raetam and its acclimation to the desert ecosystem and its ability to withstand long periods of drought is a result of a combination of biochemical, molecular and structural mechanisms. Armiard et al. (2003) found that drought stress increase galactinol in plants due to the significant increase in myo-inositol, which is the precursor of 
galactinol. Working on Arabidopsis thaliana, under water stress conditions, Jang et al. (2004) observed the expression of a protein that facilitates water transport across the plasma membrane.

Trials of exogenous application of different growth regulating substances under normal irrigation conditions to improve growth and/or to counteract adverse effects on plant growth caused by abiotic stress conditions on a variety of plants were carried out by many authores e.g. (Sinha and Varma, 1974; El-Gamassy et al., 1980; El-kady et al., 1980; Kepczynski, 1986; Kaber and Beltepe, 1989; Reynolds, 1989; Sheo and Singh, 1999). The adverse effects of osmotic stress on Ceratoides lanata was alleviated by exogenous application of kinetin and not by gibberrellic acid treatment (Khan et al. 2004).

Zin-Huang et al. (1997) after their in vitro studies on soybean hypocotyls reported that the treatment with kinetin increased callus growth not only because it plays a role in cell division but also because it lowers the rate of degradation of endogenous IAA.

The various physiological responses of plants usually obtained after application of growth regulating substances or phytohormones is largely dependent on the effect of such substances on gene activation or gene expression, and accordingly on gene products like mRNA and respective proteins. GA3, for example, is known to trigger the synthesis of several hydrolytic enzymes (Baulcombe et. al. 1986, Ho et. al. 1987). Dhindsa et al. (1987), working on mung bean seedlings, observed the appearance of novel auxin induced proteins in the protein electrophoretic patteren. A number of nuclear encoded mRNAs for chloroplast protein were suggested to be controlled at the transcript level by cytokinins (Funckes Shippy and Levine, 1985). Reports indicate that cytokinins (e.g. kinetin) mediate the synthesis and maintenance of various proteins. Che et al. (2002) observed that phytohormones activated special genes and some physiological responses (like shoot development) in Arabidobsis.

In the present study, trials were conducted to through some light on the effect of water stress and growth regulators on some gene products (proteins) and the subsequent effects on growth of fenugreek.

\section{Materials and Methods}

The seeds of fenugreek (Trigonella foenum-graecum) were planted in black polyethylene bags $(20 \mathrm{~cm}$ in diameter). Each bag contained one kilogram soil. Plants were grown under natural temperature and irrigation conditions for 10 days and then they were divided into 3 main groups. The first one was irrigated daily to keep it at full field capacity (normal irrigation conditions), the second at $50 \%$ of its field 
capacity (S1) and the third at $25 \%$ (S2). This was carried out by weighing a sample of the soil and adding the required amount of water (lost water). Each one of the three main groups was subdivided into 4 subgroups. The first was kept as control, the second was sprayed with $\mathrm{GA}_{3}$ (1000 p.p.m), the third with IBA (100 p.p.m), and the fourth with kinetin (100 p.p.m). Each treatment was represented by three replicates. Two weeks after treatment, samples were collected for the measurement of growth characters (shoot and root length and fresh weight), the samples were dried in anoven at $50{ }^{\circ} \mathrm{C}$ until constant dry weights were obtained for determination of shoot and root dry weights. Accurately, $0.1 \mathrm{gm}$ from the youngest and fully expanded leaves was taken for the sodium dodecylesulphate polyacrylamide gel electrophoresis of proteins (SDS-PAGE) to study the gene expression under the effect of water stress and the application of some growth regulators treatment. Extraction for protein determination was carried out using Tris buffer, PH 7.5 (Jonathan and Weaden 1990). Protein fractionation was carried out according to the method of Laemelli (1970). Results of the present study were analyzed statistically according to (Steel and Torry 1980).

\section{Results and Discussion}

Results of the present study, as illustrated in table (1) and figure (2), declare that water stress reduced some of the measurements of the vigor of growth of fenugreek as shoot length, fresh and dry weights while the root length was enhanced, especially by the moderate stress (S1). Such enhancement was not accompanied by any increases of neither the fresh nor the dry weight. It was generally observed that the roots became longer but not abundant. Such responses have been observed by many authors as a part of their extensive studies on stress physiology (Singh-Sangwan et al., 1994; Banuls et al., 1997 Al-Hakimi et al., 2001; Al-Hakimi, 2003; Abdul Baset, 2005; Celina et al. 2005). Under the effect of water stress respiration rate usually increases (Collier and Cummins 1992) while the photosynthetic efficiency decreases (Di Marco et al.1988; Di Marco \& Tripoli 1993). The reduction of plant growth under water stress is a final result of a sum of complex biochemical and physiological acts including, mainly, enhanced respiration and reduced photosynthesis

The alterations observed in the protein patterns of SDS-PAGE adopted in this study may through some light on the reasons behind the above-mentioned responses. SDS-PAGE has shown that the overall number of major bands detected was 15 bands. Bands number 1, 2, 3, 4, 5, 6, 7, 10, 11, 12 and 14 (table 2) were observed in all studied samples. Twelve bands were detected in the control samples (normal irrigation conditions and no growth regulator application). Water stress changed the 
SDS-PAGE pattern. In fig. No. (3), an additional protein band could be detected on lane number 5 (S1) and lane number 9 (S2) (this band is given No. 15 in table 2, $\mathrm{RF}=0.68$ ). This stress induced band was not observed in the corresponding control or the other treatments. Such changes in protein profiles due to abiotic stresses may agree and confirm the observations carried out by other authors like (Smirhoff and Colombe, 1989; Skiver and Mundy, 1990; Luchi et al., 1996; shinozaki and Yamaguchi-Shinozaki, 1996; Bray, 1997; Oliver et al., 1998; Tabaeizadeh, 1998). There is a general and strong agreement now that subjecting plants to abiotic stress such as water or salt stresses affect gene expression by enhancing genes to signal for the biosynthesis of osmoprotective proteins and this may lead to both qualitative and quantitative differences between normal and stressed plants in the protein electrophoretic patterens and this may also be the reason of alteration of cell enzymatic activities and gross biochemical changes in the cell like reduction in photosynthetic activity (Ritchie et.al. 1990), accumulation of organic acids such as malate, citrate and lactate and osmoprotective substances like proline, sugars and betaine (Bohnert et. al., 1995; Shinozaki and Yamaguchi-Shinozaki, 1996; Bray, 1997; Tabaeizadeh, 1998).), and an overall reduction in protein synthesis (Mason et. al., 1988) and an overall reduction in the vigor of plant growth ( as obtained in this study). The results of the present study may also agree with the result obtained by Jang et. al. (2004) who observed, in the protein profile, the expression of a protein that facilitates water transport (which becomes more difficult under stress conditions) across biological membranes in Arabidopsis thaliana, grown under water stress conditions. It could be included that the expression of such protein may be also as one of the defense mechanisms of plants against stress beside the other mechanisms like synthesis of osmoprotective compounds.

Table (1) and figures (2) showed that the used growth regulators tended to improve plant growth. Growth regulators could generally improve the growth of plants grown under normal irrigation conditions and counteract some of the adverse effects of abiotic stress in the present study. Simillar results were also observed in the work of other authors (Sinha and Varma, 1974; El-Gamassy et al., 1980; El-kady et. al., 1980; Kepczynski, 1986; Kaber and Beltepe, 1989; Reynolds, 1989; Sheo and Singh, 1999; Khan et. al. 2004). Improvement of plant growth by growth regulators may be explained on the basis that growth regulators enhance many cellular physiological activities like cell division, cell elongation and the biosynthesis of many cellular stress osmoprotective materials. Results of the present study (table 2 and figure 3) may explain such responses. 
Treatment with $\mathrm{GA}_{3}$ under normal irrigation conditions and the second level of water stress (S2) resulted in the appearance of two novel bands; band number 9 $\left(\mathrm{R}_{\mathrm{F}}=0.41\right)$ and band number13 $\left(\mathrm{R}_{\mathrm{F}}=0.62\right)$ in lanes ( 2 and 10$)$. This may indicate the effect of $\mathrm{GA}_{3}$ on gene expression and products. In figure 3, lane 5, under the first level of water stress ( $\mathrm{S} 1$ ), a new protein band (number 15 in table $2, \mathrm{R}_{\mathrm{F}}=0.68$ ), was observed. This new band, which appeared under stress conditions disappeared when the stressed plants were treated with $\mathrm{GA}_{3}$ (figure 3, lane 6). It may be concluded that $\mathrm{GA}_{3}$ may have alleviated the adverse effects of water-stressed plants by returning gene expression and protein profile to the normal status (as in the control plants). Under the second level of water stress (S2) this band (stress induced band) appeared again and the $\mathrm{GA}_{3}$ treatment resulted not only on the disappearance of it but also the appearance of two additional bands ( $9 \& 13$ in table 2$)$. The results obtained in this study may agree with the work of other authors who stated that $\mathrm{GA}_{3}$ trigger the synthesis of several hydrolytic enzymes (Baulcombe e.t al. 1986, Ho et. al. 1987). Under normal irrigation conditions, IBA (table 2 and lane 3 in figure 3 ) resulted in the absence of a band that presents in its corresponding control (band No. 8). On the contrary of this result, Dhindsa et. al. (1987) observed the appearance of novel auxin induced proteins. In the present study IBA resulted in the occurrence of an additional band (band No. 9- $\mathrm{R}_{\mathrm{F}}=0.41$ ) but only under severe stress conditions. However, the type of response to hormonal treatment may depend on the species studied or the physiological status of the plant.

Under the second level of water stress (lane 12 in Figure 3), (see also table 2), kinetin resulted in the over-expression of band No. 4 which presents also in the corresponding control. Regarding the effect of cytokinins on protein electrophoretic patterens, a number of reports indicate that cytokinins (e.g. kinetin) mediate the synthesis and maintenance of various proteins. In this regard, Funckes Shippy and Levine (1985) and indicated that a number of nuclear encoded mRNAs for chloroplast protein is controlled at the transcript level by cytokinins.

\section{Conclusion}

The growth and the leaf proteins of fenugreek were affected by water stress and treatment with growth regulators. Water stress resulted in the reduction of some growth characters and induced an additional protein band. Growth regulators improved some of the growth parameters of fenugreek grown under normal irrigation conditions and alleviated the adverse effects of water stress on plants. $\mathrm{GA}_{3}$ treatment under normal irrigation conditions induced two additional protein bands. The stress induced novel protein band was absent after $\mathrm{GA}_{3}$ treatment. IBA, under normal irrigation resulted in the disappearance of a protein band that presents in the 
corresponding control. Under severe water stress, IBA resulted in the appearance of an additional protein band. Kinetin treatment resulted in the over expression of one the common or characteristic protein bands. The obtained results may through some light on the interactive effects of water stress, growth substances on growth and gene activity of fenugreek.

Table (1): Effect of water stress and growth regulators on some growth parameters of fenugreek

\begin{tabular}{|c|c|c|c|c|}
\hline \multicolumn{5}{|c|}{ (a): Shoot length $(\mathrm{cm})$} \\
\hline G. Sub. & None & $\mathrm{GA}_{3}$ & IBA & $\mathrm{Ki}$ \\
\hline Cont. & $12.4 \pm 0.53$ & $14.66 \pm 0.21 *$ & $9.30 \pm 0.15^{*}$ & $9.73 \pm 0.15^{*}$ \\
\hline Stress1 & $11.76 \pm 0.43 *$ & $15.53 \pm 0.20^{*}$ & $8.83 \pm 0.33 *$ & $9.46 \pm 0.33^{*}$ \\
\hline Stress2 & $8.10 \pm 0.26 *$ & $8.76 \pm 0.19 *$ & $8.16 \pm 0.24$ & $9.03 \pm 0.23^{*}$ \\
\hline \multicolumn{5}{|c|}{$\mathrm{LSD}=0.394$ at $(\mathrm{P}=0.05)$} \\
\hline \multicolumn{5}{|c|}{ (b): Shoot fresh weight $(\mathrm{g})$} \\
\hline G.Sub. & None & $\mathrm{GA}_{3}$ & IBA & $\mathrm{Ki}$ \\
\hline Control & $0.43 \pm 0.01$ & $0.45 \pm 0.01 *$ & $0.44 \pm 0.00$ & $0.45 \pm 0.01 *$ \\
\hline Stess 1 & $0.39 \pm 0.00 *$ & $0.41 \pm 0.01 *$ & $0.35 \pm 0.03 *$ & $0.39 \pm 0.01 *$ \\
\hline Stress2 & $0.32 \pm 0.02 *$ & $0.31 \pm 0.00$ & $0.27 \pm 0.00 *$ & $0.30 \pm 0.00 *$ \\
\hline \multicolumn{5}{|c|}{$\mathrm{LSD}=0.016$ at $(\mathrm{P}=0.05)$} \\
\hline \multicolumn{5}{|c|}{ (C): Shoot dry weight $(g-1)$} \\
\hline G.Sub. & None & $\mathrm{GA}_{3}$ & IBA & $\mathrm{Ki}$ \\
\hline Control & $0.51 \pm 0.02$ & $0.52 \pm 0.01$ & $0.52 \pm 0.02$ & $0.56 \pm 0.00 *$ \\
\hline Stess 1 & $0.43 \pm 0.02 *$ & $0.47 \pm 0.02 *$ & $0.42 \pm 0.03$ & $0.45 \pm 0.03$ \\
\hline Stess1 & $0.38 \pm 0.01 *$ & $0.35 \pm 0.01 *$ & $0.35 \pm 0.01 *$ & $0.35 \pm 0.01 *$ \\
\hline \multicolumn{5}{|c|}{$\mathrm{LSD}=0.026$ at $(\mathrm{P}=0.05)$} \\
\hline \multicolumn{5}{|c|}{ (d): Root length $(\mathrm{cm})$} \\
\hline G. Sub & None & $\mathrm{GA}_{3}$ & IBA & $\mathrm{Ki}$ \\
\hline cont & $10.43 \pm 0.20$ & $12.43 \pm 0.24 *$ & $15.26 \pm 0.31 *$ & $13.20 \pm 0.21 *$ \\
\hline Stress1 & $13.86 \pm 0.20 *$ & $13.40 \pm 0.06 *$ & $14.86 \pm 0.20 *$ & $9.46 \pm 0.26^{*}$ \\
\hline Stress2 & $12.60 \pm 0.56^{*}$ & $10.93 \pm 0.22 *$ & $12.86 \pm 0.22$ & $15.20 \pm 0.49 *$ \\
\hline \multicolumn{5}{|c|}{$\mathrm{LSD}=0.424$ at $(\mathrm{P}=0.05)$} \\
\hline \multicolumn{5}{|c|}{ (e): Root fresh weight (g) } \\
\hline G.Sub. & None & $\mathrm{GA}_{3}$ & IBA & $\mathrm{Ki}$ \\
\hline Control & $0.161 \pm 0.004$ & $0.208 \pm 0.005^{*}$ & $0.286 \pm 0.007 *$ & $0.164 \pm 0.004$ \\
\hline Stess 1 & $0.151 \pm 0.004^{*}$ & $0.145 \pm 0.002$ & $0.286 \pm 0.008 *$ & $0.168 \pm 0.005^{*}$ \\
\hline Stress2 & $0.149 \pm 0.002$ & $0.155 \pm 0.005 *$ & $0.169 \pm 0.002 *$ & $0.154 \pm 0.00$ \\
\hline \multicolumn{5}{|c|}{$\mathrm{LSD}=0.006$ at $(\mathrm{P}=0.05)$} \\
\hline \multicolumn{5}{|c|}{ (f) Root dry weight (g -1) } \\
\hline G.Sub. & None & $\mathrm{GA}_{3}$ & IBA & $\mathrm{Ki}$ \\
\hline Control & $0.160 \pm 0.009$ & $0.191 \pm 0.005^{*}$ & $0.272 \pm 0.008 *$ & $0.160 \pm 0.008$ \\
\hline Stess 1 & $0.143 \pm 0.008^{*}$ & $0.160 \pm 0.004 *$ & $0.242 \pm 0.004 *$ & $0.154 \pm 0.002 *$ \\
\hline Stress2 & $0.141 \pm 0.005^{*}$ & $0.159 \pm 0.006 *$ & $0.153 \pm 0.001 *$ & $0.127 \pm 0.006^{*}$ \\
\hline \multicolumn{5}{|c|}{$\mathrm{LSD}=0.0087$ at $(\mathrm{P}=0.05)$} \\
\hline
\end{tabular}

Each value is a mean of three determinations, $*=P>0.05$ 
Table (2): Summery of densitometric analysis of fenugreek leaf water soluble protein profile.

\begin{tabular}{|c|c|c|c|c|c|c|c|c|c|c|c|c|c|}
\hline $\begin{array}{c}\text { Band } \\
\text { No. }\end{array}$ & $\mathrm{Rf}$ & $\mathrm{C}$ & $\mathrm{GA}_{3}$ & $\mathrm{IBA}$ & $\mathrm{Ki}$ & $\mathrm{S} 1$ & $\begin{array}{c}\mathrm{S} 1 \\
+ \\
\mathrm{GA}_{3}\end{array}$ & $\begin{array}{c}\mathrm{S} 1 \\
+ \\
\mathrm{IBA}\end{array}$ & $\begin{array}{c}\mathrm{S} 1 \\
+ \\
\mathrm{Ki}\end{array}$ & $\begin{array}{c}\mathrm{S} 2 \\
+\end{array}$ & $\begin{array}{c}\mathrm{S} 2 \\
+ \\
\mathrm{IBA}\end{array}$ & $\begin{array}{c}\mathrm{S} 2 \\
+ \\
\mathrm{Ki}\end{array}$ \\
\hline 1 & 0.08 & + & + & + & + & + & + & + & + & + & + & + & + \\
\hline 2 & 0.12 & + & + & + & + & + & + & + & + & + & + & + & + \\
\hline 3 & 0.15 & + & + & + & + & + & + & + & + & + & + & + & + \\
\hline 4 & 0.19 & + & + & + & + & + & + & + & + & + & + & + & ++ \\
\hline 5 & 0.24 & + & + & + & + & + & + & + & + & + & + & + & + \\
\hline 6 & 0.28 & + & + & + & + & + & + & + & + & + & + & + & + \\
\hline 7 & 0.34 & + & + & + & + & + & + & + & + & + & + & + & + \\
\hline 8 & 0.38 & + & + & - & + & + & + & + & + & + & + & + & + \\
\hline 9 & 0.41 & - & + & - & - & - & - & - & - & - & + & + & - \\
\hline 10 & 0.43 & + & + & + & + & + & + & + & + & + & + & + & + \\
\hline 11 & 0.49 & + & + & + & + & + & + & + & + & + & + & + & + \\
\hline 12 & 0.53 & + & + & + & + & + & + & + & + & + & + & + & + \\
\hline 13 & 0.62 & - & + & - & - & - & - & - & - & - & + & - & - \\
\hline 14 & 0.66 & + & + & + & + & + & + & + & + & + & + & + & + \\
\hline 15 & 0.68 & - & - & - & - & + & - & - & - & + & - & - & - \\
\hline
\end{tabular}

$+=$ Present band, $++=$ over-expressed band, $-=$ absent band

Fig. No. (1): Photos of fenugreek plants after 2 weeks of treatment with water stress and some of plant growth regulators

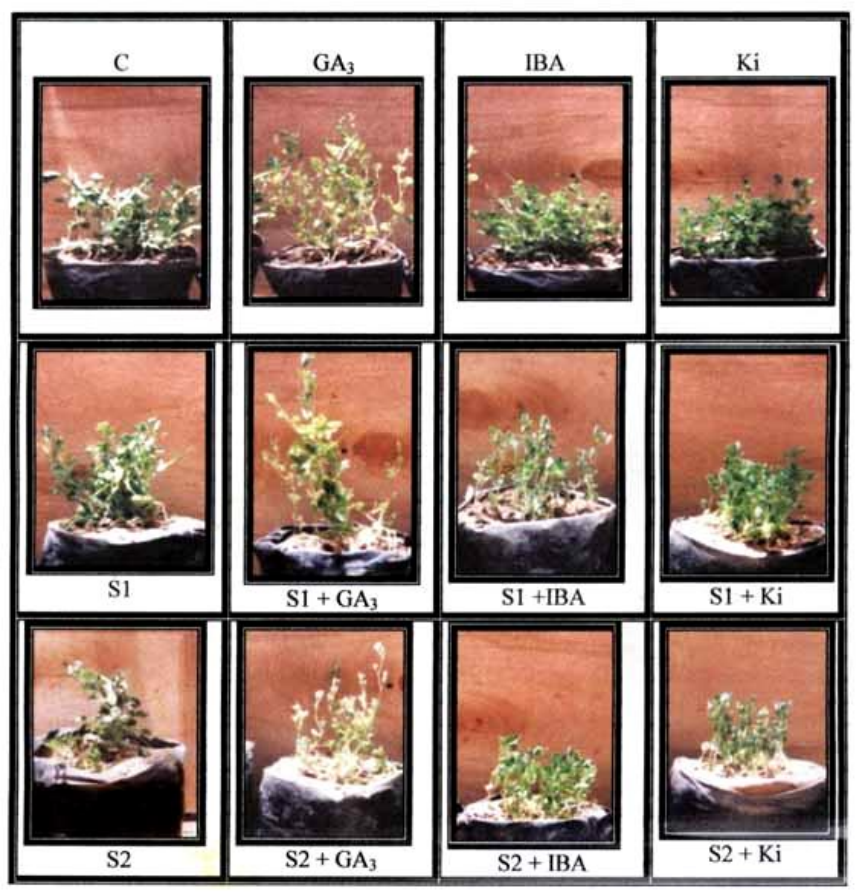


Figure No. (2): Effect of water stress and growth regulators on some growth parameters of Fenugreek plants.

(a): Effect of water stress and growth regulators on shoot length $(\mathrm{cm})$

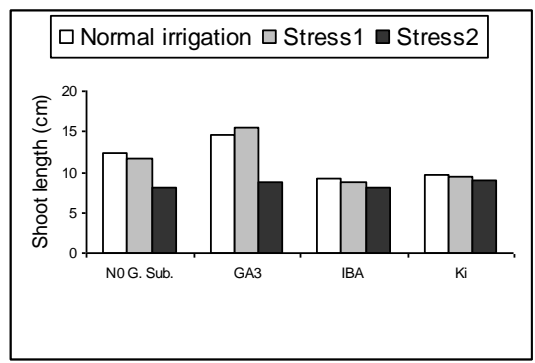

Figure (b): Effect of water stress and growth regulators on shoot fresh weight (g)

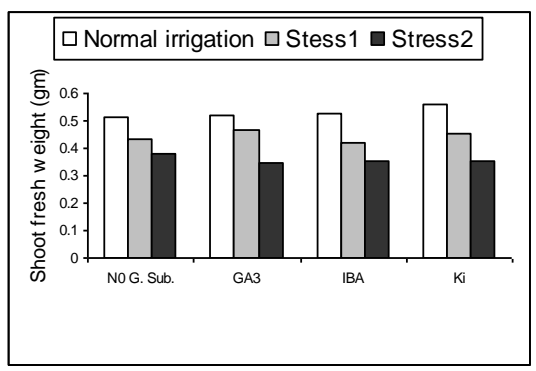

Figure (c): Effect of water stress and growth regulators on shoot dry weight $(g-1)$

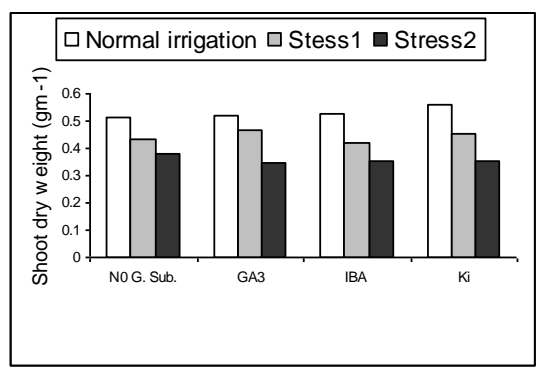

(d): Effect of water stress and growth regulators on root length $(\mathrm{cm})$

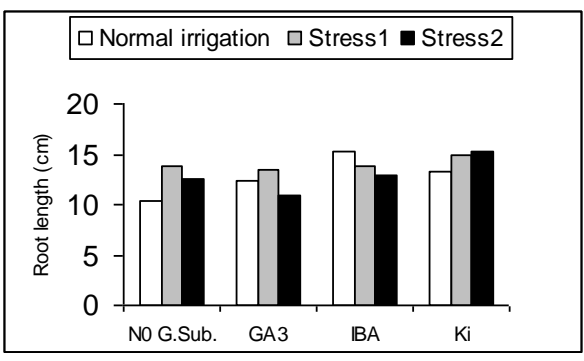

Figure (e): Effect of water stress and growth regulators on root fresh weight (g)

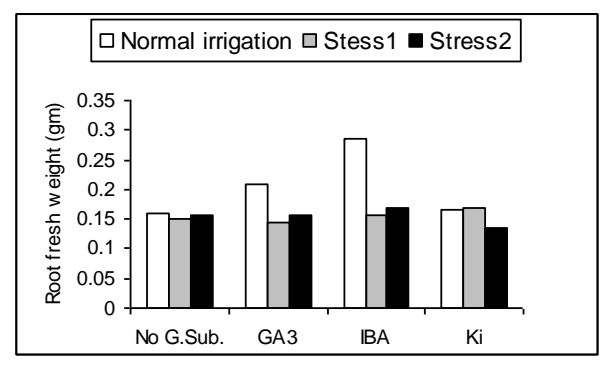

Figure (f): Effect of water stress and growth regulators on root dry weight $(g-1)$

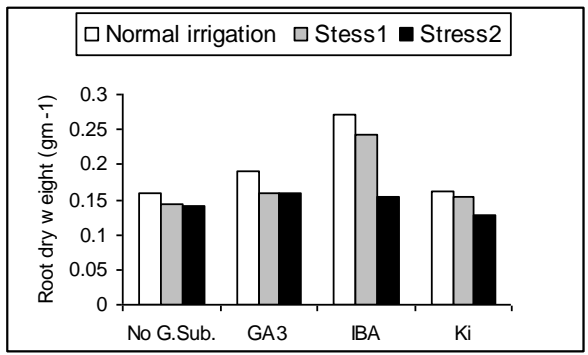


Figure (3): SDS-PAGE of fenugreek leaf water soluble protein.

1 (control), 2 (GA $)$ ), 3 (IBA), 4 (Ki), 5 (S1), 6 (S1+GA $)$, 7(S1+IBA), 8 (S1+Ki), 9 (S2), 10 $\left(\mathrm{S} 2+\mathrm{GA}_{3}\right), 11(\mathrm{~S} 2+\mathrm{IBA}), 12(\mathrm{~S} 2+\mathrm{Ki}), \mathrm{M}$ (marker)

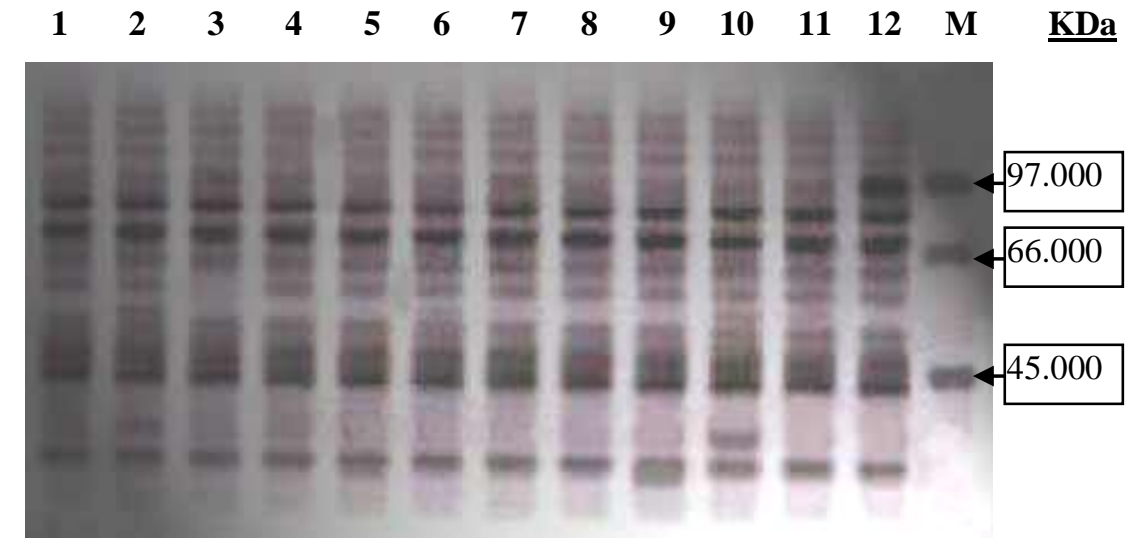

\section{References}

1. ABDUL-BASSET, M.A. (2005). Counteraction of drought stress and calcium on the growth of Zea mays plants. Yemeni J. Biol. Sci. 1: 1-11.

2. Al-HAKIMI, A.M.A. (2003). Physiological responses of sunflower seedlings growing under drought stress. FSB.16:169-176.

3. Al-HAKIMI, A.M.A., HAMAD, A.M.A., ABDUL-BASSET, R. AND ZIDAN, M.A. (2001). Calcium drought interactions on growth, photosynthetic pigments, gas exchange and mineral element contents of sunflower plants. J.Union Arab Biol. 8: 51-63.

4. ARMIRAD, V.; MORYAN, B.; BILLARD, J; HUAULT, C.; KELlER, F. AND PRUD'HOMME, M. (2003). fractans but not sucrosyl-galactoside, raffinose and loliose are affected by drought stress in perennial ryegrass. Pl. Physiol.132: 2218-2229.

5. BANULS,J.; SERNA, D.S.; LEGAZ, F.; TALON, M. AND PRIMO-MILLO, E. (1997). Growth and gas exchange parameters of Citrus plants stressed with different salts. J. Pl. Physiol. 150: 194-199.

6. BAULCOMBE, D. C.; MARTIENSSEN, R.A.; HUTTLY, A.M. AND LAZARUS, C.M. (1986). Hormonal and development control of gene expression in wheat. Phill. Trans..Soc.London B. 314: 441-451

7. BOHNERT, H.J.; NELSON, D.E.; AND JENSEN, R.G. (1995). Adaptations to environmental stresses. Plant Cell 7:1099-1111. 
8. BRAY, E.A. (1997). Plant responses to water deficit. Trends in Plant Science 2:48-54.

9. CELINA, M. L.; GABRIELA M. P.; SIMON D.; KARIN G.; STEPHANIE B.; AND CHRISTINE H. F. (2005). Drought controls on $\mathrm{H}_{2} \mathrm{O}_{2}$ accumulation, catalase (CAT) activity and $C A T$ gene expression in wheat. J. Exp. Bot. 56, 411: 417-423.

10. CHE, P.; GINGERICH, D.J.; LALL, S AND HOWELL, S.H. (2002). Global and hormone induced gene expression during shoot development in Arabidobsis. Plant Cell, 14(11):2771-2785.

11. COLLIER, D.E. \& CUMMINS, W.R. (1992).Stimulation of respiration during plant water deficits in sand-growth arnica alpine. In Molecular, Biochemical and PhysiologicalAspects of Plant Respiration (H. Lambers and L.H. W. van der plas, eds.), $541-546$

12. DHINDSA, R.S.; DONG,G. AND LALONDE, L. (1987). Altered gene expression during auxin induced root development from excised mung bean seedlings. Plant Physiol. 84: 1148-1153.

13. DI MARCO, G.A.; MASSACCI, A. \& GABRIELLA, R. (1988). Drought effect on photosynthesis and fluorescence in hard wheat cultivars grown in the field. Physiol. Plant.124: 385-390.

14. DI MARCO, G.A. \& TRIPOLI, D. (1993). Effect of water deficit on photosynthesis and electron transport in wheat grown in a natural environment. J. Plant Physiol.124: 156-160.

15. EL-GAMASSY, A.M.; EL-GENDY, S.A.; EL-GAMASSY, K.M. AND EL-DEIB, S.A. (1980). Studies on some cultural treatments on the growth and active ingredients contents of Atropa belladonna plants. I- Effect of spraying with GA3. Ann. Agric. Sci. Fac. Agric. Ain Shams Univ. Cairo, Egypt, 25 (1\&2): 299-311.

16. EL-KADY, M.M.; MANSOUR, M.A.; AND SORIAL, M.E. (1980). Effect of some growth regulators on growth, flowering and yield of Datura plant. Monofeia J. Agri. Res. Vol. (3):53-71.

17. FUNCKES SHIPPY, C.L. AND LEVINE, A.D. (1985). Cytokinin regulates the expression of nuclear genes required for photosynthesis. In: Molecular Biology of the Photosynthetic Apparatus (Eds. Steinback,K.E.; Bonitz, S.; Arentzen, C.J. and Bogorad, L. ) pp. 407-411.Cold Spring Harbor Lab.

18. HO, T.D.; NOLAN, R.C.; LIN, L.; BRODL, M.R. AND BROWN, P.H. (1986). Regulation of gene expression in barley aleurone layers. In: Molecular Biology of Plant Growth Control, pp.35-49 (Eds. Fox,G.E.; and Jacobs, M.). Alan Liss Inc., New York.

19. HUSSEIN, E. A. (1993). Studies on the Effect of water Stress and The treatment with some growth substances on Datura stramonium, M.SC. Thesis, Faculty of Science, AlAzhar Univ. Cairo, Egypt. 
20. JANG,Y. J.; DONG, G.U..; KIM, D.G.; KIM, Y.O.; KIM, J.S. and KANG, H. (2004). An expression analysis of a gene family encoding plasma membrane aquaporins in response to abiotic stresses in Arabidopsis thaliana. Plant Mol. Biol. 54, 5: 713-725.

21. JONATHAN, F.W. and WEADEN, N.F. (1990). Visualization and interpretation of plant isoenzymes.In Solites, D.E. and P.S. Solites (eds.). Isozymes in plant biology, London Chapman and Hall, pp.45-55.

22. KABER, K. and BELTEPE, S. (1989). Effect of kinetin and gibberellic acid in overcoming high temperature and salinity $(\mathrm{NaCl})$ stresses on the germination of barley and lettuce seeds. Phyton (Buenos Aires), 30: 65-74.

23. KEPCZYNSKI, J. (1986). Inhibition of Amaranthus caudatus seed germination by polyethylene glycol-6000 and abscisic acid and its reversal by ethephon or 1aminocyclopropane-1-carboxylic acid. Physiol. Plant. 67: 588-591.

24. KHAN, M.A.; GUL, M.; AND WEBER, D.J.; (2004). Action of plant growth regulators and salinity on seed germination of Ceratoides lanata. Can.J. Bot., 2:37-41.

25. LAEMELLI, U.K. (1970). Cleavage of structural proteins during the assembly of the head of bacteriophage T4. Nature, 2227: 680-685.

26. LILACH, P.; ELZA, H.; MIRA, R.; MIRA, C.; PIERRE, G.; AARON, K. AND RON, M. (2002). Molecular and biochemical mechanisms associated with dormancy and drought tolerance in the desert legume Retama raetam. The Plant Journal, 31:319-323.

27. LUCHI, S.; YAMAGUCHI-SHINOZAKI, K.; URAO, T.; TERAO, T. AND SHINOZAKI, K. (1996). Novel drought-inducible genes in the highly drought-tolerant cowpea: cloning of cDNAs and analysis of the expression of the corresponding genes. Plant and Cell Physiology 37:1073-1082

28. MASON, H.S.; GUERREO, F.D.; BOYER, J.S. AND MULLET, J.E. (1988). Proteins homologous to leaf glycoproteins are abundant in stem of dark grow soybean seedlings. Plant Molecular Biology 11:845-856.

29. OLIVER, M.J.; WOOD, A.J. AND O'MAHONY, P. (1998). To dryness and beyond preparation for the dried state and rehydration in vegetative desiccation-tolerant plants. Plant Growth Regulation 24:193-201.

30. POLHIL, R.M.; RAVEN, P.H. (1981). Advances in legume systematic. Royal Botanical Gardens, Kew, England.

31. RAJAGOPALAN, M.S. (1998): Fenugreek, what this herb can offer? Naturally, 1:1-4.

32. REYNOLDS, T.L. (1989). Changes in RNA, protein and translatable messenger RNA synthesis and accumulation during adventive organogenesis in osmotic tissue culture of Solanum carolinese. Plant Science Limerick, 65, 1: 77-85. 
33. RITCHIE, S.W.; NGUYEN, H.T. AND HOLADAY, A.S. (1990). Leaf water content and gas exchange parameters of two wheat genotypes differing in drought resistance. Crop Science 30:105-111.

34. SHARMA, R.D. (1990). Effect of fenugreek on blood glucose and serum lipids in type-1 diabetes. European Journal of Clinical Nutrition; 44:301-306.

35. SHEO, G. AND SINGH, I.P. (1999). Effect of foliar application of urea, GA3 and ZnSO4 on seedling growth of two citrus species. J. Appl. Hort., 1 (1): 51-53.

36. SHINOZAKI, K. AND YAMAGUCHI-SHINOZAKI, K. (1996). Molecular responses to drought and cold stress. Current Opinion Biotechnology 7:161-167.

37. SINGH-SANGWAN, N.; FAROOKI, A.H.A. AND SANGUAN, R.S. (1994). Effect of drought stress and essential oil metabolism in lemon grass. New. Phytol. 128: 173-179.

38. SINHA, A.S. AND VARMA, K.C. (1974). Infeluence of Indol-3-acetic acid on growth and alkaloid content in Datura innoxia. Indian Drug Pharma.12, 1: 51-54. (C.F. Chem. Abst. 48, 19: 1488996).

39. SKRIVER, K. and MUNDY, J. (1990). Gene expression in response to abscisic acid and osmotic stress. Plant Cell. 2: 503-512.

40. SMIRHOFF, N. and COLOMBE, S.V. (1989). Drought infeluences the activity of enzymes of the chloroplast hydrogen peroxide scavenging system. J. Exp. Bot. 39: 10971080 .

41. STEEL, R.G. AND TORRY, J.H. (1980). Principles and Procedures of Statistics. Mc Graw-Hill Book Company Inc., New York/London.

42. TABAEIZADEH, Z. (1998). Drought-induced responses in plant cells. International Review of Cytology 182:193-247.Wangaxia, W.; Basia, V. and Arie, A. (2003). Plant responses to drought, salinity and high temperatures: towards genetic engneering for stress tolerance. Planta, 218, 1: 1-14.

43. ZIN-HUANG LIU; WEI-CHANG WANG AND SHO-YAN (1997). Effect of hormone treatment on callus formation and endogenous indol-acetic acid and polyamine contents of soybean hypocotyle cultivated in vitro. Bot. Bull. Acad. Sci. 38: 171-176. 


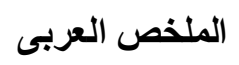

\section{نمو ويروتينات الورقة لنباتات الحلبة النامية تحت ثأثير}

نقص الإمداد المائى والمعاملة ببعض منظمات النمو

* عصام عبد السلام حسين و ** محمد أحمد الشميرى

* قسم النبات و الميكروييولوجى/ كلية العلوم/جامعة الأزهر/مدينة نصر/ القاهرة /ج.م.ع. ** قسم البيولوجى / كلية العلوم/جامعة صنعاء/ اليمن

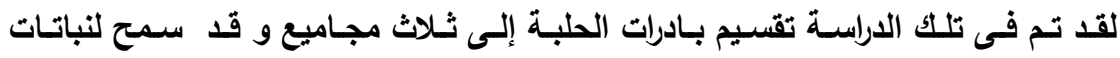
المجموعة الأولى منها بالنمو تحت ظروف رى ( السعة الحقلية الكاملة) و الثانية تحت إجهاد

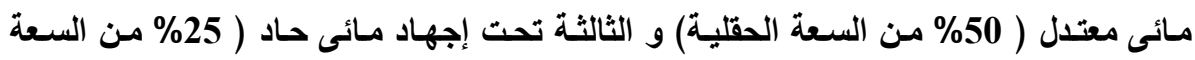
الحقلية) ثم قسمت كل مجموعة إلى أريعة تحت مجاميع جعلت الأولى منها ضـابطة و عوملت الثانيـة بـ 1000 جزئ فى المليون من جبريللين والثالثة بـ 100 جزئ فى المليون مـن إندول حامض بيوتيريك والرابعة بـ 100 جزئ فى المليون من كينيتين ثم تم تجميع العينات بعد أسبوعين

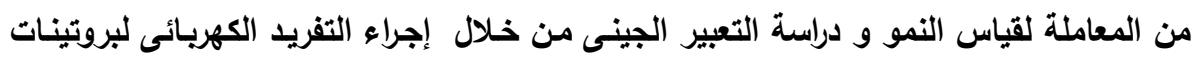
الورقة ـ لقد أدى استخدام منظمات النمو الى تحسين نمو النبات تحت ظروف الرى العادى و إزالة

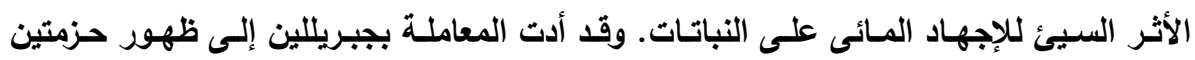
بروتينيتين جدياتين تحت ظروف الرى العادى كما أعادت ظهور حزمـة بروتينية أخرى قد اختفت نتيجة نقص الإمداد المائى. كما أدت المعاملة بإندول حامض بيوتيريك إلى إختفاء إحدى الحزئي البروتينية مقارنة بالمجموعة الضابطة أما كينيتين فقد عمل على زيادة التعبير فى حزمة بروتينية 